The seasonal effect may be an acute response to ambient temperature, perhaps initiated by a sympathetic reflex initiated by skin cooling. This would accord with the known responses to the "cold pressor test," which increase with age. It is perhaps surprising that the effect seems largely uninfluenced by treatment, especially with a beta-blocker, but the dose used in the trial is not enough to abolish sympathetic activity.

These data provide further evidence that environmental temperatures affect arterial pressure in middle-aged men and women with mild hypertension. The influence of seasonal factors on the blood pressures of normotensive or severely hypertensive subjects or on the blood pressures of the elderly may differ. When the full trial results are available it may be possible to estimate the effect of seasonally related blood pressure increase on cardiovascular morbidity and mortality in the middle-aged mild hypertensives who make up the trial population. It would, however, be unwise to extrapolate from these results for this selected group and attempt this estimation for other populations.

We thank the MRC Working Party on mild/moderate hypertension (whose members include: Professor W S Peart, chairman; Mrs G R Barnes; Mr P Broughton; Professor C T Dollery; Dr K G Green; Dr G Greenberg; Dr M F Hudson; Dr A F Lever; Dr T $\mathbb{W}$ Meade; Professor G A Rose; and $\mathrm{Dr} W \mathrm{E}$ Miall, secretary) for permission to publish these data while the trial is still in progress, and the nurses and doctors participating in the study who made all the blood pressure measurements. Meteorological data were kindly provided by the Meteorological Office, Bracknell. Thanks are also due to Imperial Chemical Industries Ltd (for generous financial support and for tablets of propranolol and its placebo); to Glaxo Operations UK Ltd (for tablets of bendrofluazide and its placebo); to Merck Sharp \&
Dohme Ltd (for providing a mobile screening unit and its running expenses and for supplies of methyldopa); and to Ciba Laboratories (for supplies of guanethidine).

Requests for reprints should be addressed to Mr P J Brennan, MRC Epidemiology \& Medical Care Unit, Northwick Park Hospital, Watford Road, Harrow, Middx HA1 3UJ.

\section{References}

1 Wright BM, Dore CF. A random-zero sphygmomanometer. Lancet 1970 ; : $: 337-8$.

${ }^{2}$ Rose G. Standardisation of observers in blood pressure measurement. Lancet 1965 ; : $: 673-4$.

${ }^{3}$ Rose G. Seasonal variation in blood pressure in man. Nature $1961 ; 189$ : 235.

4 Heller RF, Rose G, Tunstall-Pedoe HD, Christie DGS. Blood pressure measurement in the United Kingdom Heart Disease Prevention Project. $\mathcal{F}$ Epidemiol Community Health 1978;32:235-8.

${ }^{5}$ Hata T, Ogihara T, Maruyama A, et al. The seasonal variation of blood pressure in patients with essential hypertension. Clinical and Experimental Hypertension-Theory and Practice 1982;A4:341-54.

${ }^{6}$ Bull GM. Meteorological correlates with myocardial and cerebral infarction and respiratory disease. British fournal of Preventive and Social Medicine 1973;27:108-13.

${ }^{7}$ Rose G. Cold weather and ischaemic heart disease. British fournal of Preventive and Social Medicine 1966;20:97-100.

${ }^{8}$ Bull GM, Morton J. Environment, temperature and death rates. Age Ageing 1978;7:210-24.

9 Bull GM, Brozovic M, Chakrabarti R, et al. Relationship of air temperature to various chemical, haematological and haemostatic variables. f Clin Pathol 1979;32:16-20.

(Accepted 22 fune 1982)

\title{
Fungal arthritis simulating juvenile rheumatoid arthritis
}

\author{
J HAAPASAARI, R V ESSEN, A KAHANPÄÄ, ANJA A I KOSTIALA, K HOLMBERG, J AHLQVIST
}

\begin{abstract}
Petriellidium boydii is often isolated from maduromycosis but has recently been associated with arthritis. $A$ previously healthy 6-year-old boy developed chronic purulent arthritis of the knee after a bicycle accident. Culture of aspirate grew no pathogens and antibiotic treatment had no effect. Culture of synovial fluid grew $P$ boydii, which responded initially to amphotericin but reappeared after six months. Subsequent treatment with miconazole was stopped after development of haema-
\end{abstract}

Rheumatism Foundation Hospital, SF-18120 Heinola 12, Finland

J HAAPASAARI, MB, paediatrician

R V ESSEN, MB, laboratory physician-in-chief

Department of Bacteriology and Immunology, University of Helsinki, SF-00290 Helsinki 29

A KAHANPÄ $\ddot{A}, M D$, docent of clinical mycology

ANJA A I KOSTIALA, MD, docent of clinical immunology

Section of Mycology, National Bacteriological Laboratory, S-10521 Stockholm

K HOLMBERG, MD, professor

Department of Pathology, Aurora Hospital, SF-00250 Helsinki 25 J AHLQVIST, MD, head turia. The fungus was sensitive to ketoconazole, and treatment with this drug cured the infection.

With the introduction of ketoconazole it is of practical importance to recognise fungal infections.

\section{Introduction}

Petriellidium boydii (perfect form: Allescheria boydii, imperfect form: Monosporium apiospermum) is best known for causing Madura foot, but lately various other associations, particularly with arthritis, ${ }^{1-3}$ have been reported from America. We believe our case to be the first from Europe.

\section{Case report}

A previously healthy 6-year-old boy injured his right knee in a bicycle accident in August 1978. The wound was cleaned and sutured without delay. Ten days later the knee became swollen and $25 \mathrm{ml}$ turbid fluid was aspirated. One week later the knee was again swollen, red, and tender, and the patient was feverish. Twenty-five ml turbid fluid was aspirated and sent for bacterial culture, which proved negative. As the patient also had raised erythrocyte sedimentation rate and C-reactive protein concentration he was admitted to hospital and treated for bacterial arthritis with various systemic and intra-articular antibiotics, but without clinical improvement. Histological examination of synovial biopsy specimens showed purulent arthritis, but repeated bacterial cultures remained negative. He was therefore sent for rheumatological evaluation in November 1978. 
On admission the patient was in fairly poor general health, and the knee was swollen, warm, and tender. Erythrocyte sedimentation rate was $122 \mathrm{~mm}$ in first hour, haemoglobin concentration was $10.8 \mathrm{~g} / \mathrm{dl}$, IgG $19 \mathrm{~g} / 1$; tests for rheumatoid factor and antinuclear antibody gave negative results. Treatment with prednisolone and hydroxychloroquine was started, and his knee was repeatedly injected with topical steroids. His condition improved generally on this regimen, ESR fell to $9 \mathrm{~mm}$ in first hour and haemoglobin concentration rose to $13.9 \mathrm{~g} / \mathrm{dl}$, but the knee remained swollen.

At arthroscopy, abundant yellowish-white material was seen in a hyperaemic joint cavity. Synovial fluid injected into blood-culture bottles showed fungal growth after four days: the fungus was identified as $P$ boydii. At microscopy of synovial fluid unusual large foamy cells were prominent but no fungal elements were found, even on review of cytocentrifugal preparations and sections from the biopsy specimen. Fluid drawn one week later gave the same results on culture and microscopy.

Tests for humoral and cellular immunity gave normal results. The patient was treated with systemic and local amphotericin B (tota 441000 IU (441 mg)) with apparent success but six months later the knee became swollen again, and $P$ boydii was isolated again. The fungus was sensitive to miconazole: treatment with this drug was started and a synovectomy performed. The drug had to be discontinued after 22 infusions because of haematuria. Amphotericin was reintroduced but stopped as transaminase values rose and fever spikes appeared. The patient was subfebrile, erythrocyte sedimentation rate was high, and the knee remained swollen and tender. Fortunately, the ketoconazole sensitivity assay performed at this point gave a minimal inhibitory concentration of $0.4-0.8 \mathrm{mg} / \mathrm{l}$. He was given 100 mg oral ketoconazole thrice daily, which produced a maximal serum concentration of $2.5 \mathrm{mg} / \mathrm{l}$ : treatment was continued for a year. The boy has been without drug treatment for 16 months with no sign of infection. His knee is painless but totally stiff.

\section{Discussion}

Fungal arthritis often develops after accidents outdoors. ${ }^{4}$ Our case shows that the disease is not encountered exclusively in warmer countries. Undoubtedly fungal arthritis is rare elsewhere, but it could appear to be even rarer, as the diagnosis may be missed by routine procedures. With the introduction of a new treatment of choice for most fungal infections ${ }^{5}$ it is of practical importance to recognise these infections.

\section{References}

${ }^{1}$ Lutwick LI, Galgiani JN, Johnson RH, Stevens DA. Visceral fungal infections due to Petriellidium boydii (Allescheria boydii). Am $\mathcal{F} \mathrm{Med}$ $1976 ; 61: 632-40$.

${ }^{2}$ Lutwick LI, Rytel MW, Yanez JP, Galgiani JN, Stevens DA. Deep infections from Petriellidium boydii treated with miconazole. $\mathcal{F} A M A$ $1979 ; 241: 272-3$.

3 Hayden G, Lapp C, Lada F. Arthritis caused by Monosporium apiospermum treated with intra-articular amphotericin B. Am f Dis Child 1977;131: 927.

4 Ehrlich GE. Fungal arthritis. $\mathcal{F} A M A$ 1978;240:563.

5 Anonymous. Ketoconazole [Editorial]. Lancet 1982;i:319-20.

\title{
Energy intake and weight gain of very low birthweight babies fed raw expressed breast milk
}

\author{
S A SPENCER, W HENDRICKSE, D ROBERTON, D HULL
}

\begin{abstract}
The energy intake and weight gain of low birthweight infants (under $1500 \mathrm{~g}$ ) fed expressed breast milk were measured. Between the second and fourth weeks of life the mean energy intake was $577 \mathrm{~kJ}(138 \mathrm{kcals}) / \mathrm{kg} /$ day and the mean weekly increase in weight $119 \mathrm{~g} /$ week. Feeding energy-rich hind milk to two babies increased their energy intake but had little effect on their rate of weight gain. There appeared to be no correlation between energy intake and weight gain, probably owing to variation in the absorption of nutrients from expressed breast milk.

This study forms a basis for a comparison of weight gain in babies fed alternative regimens of artificial milks.
\end{abstract}

\section{Introduction}

The optimal feed for preterm infants weighing less than $1500 \mathrm{~g}$ at birth is still hotly disputed. Whereas the report of the Depart-

\footnotetext{
Department of Child Health, University Hospital, Queen's Medical Centre, Nottingham NG7 2 UH

S A SPENCER, MRCP, lecturer

W HENDRICKSE, MRCP, lecturer

D ROBERTON, MRCP, MD, registrar

D HULL, FRCP, professor
}

ment of Health and Social Security's Working Party on Human Milk Banks ${ }^{1}$ suggested that banked human milk is generally agreed to be the best feed for these babies, opponents maintain that the use of such milk is little short of dangerous. ${ }^{2}$ Questions regarding bacterial contamination, heat treatment of milk, and the nutritional adequacy of expressed breast milk are raised repeatedly. Manufacturers have responded by providing feeds with alternative formulae, which need to be evaluated. To facilitate this the growth of preterm infants receiving expressed breast milk must be defined. As expressed breast milk has a very variable composition, particularly with regard to its energy content, ${ }^{3}$ any study would have little value unless some measure of the volume taken and energy content of expressed breast milk was made against which artificial milk formulae could be compared. This paper reports the weight increments of babies weighing less than $1500 \mathrm{~g}$ reared on breast milk, the energy content of which was estimated using a creamatocrit.

\section{Methods}

All surviving babies born in or transferred to Nottingham between February 1981 and February 1982 with a birth weight of less than $1500 \mathrm{~g}$ and a gestational age of less than 33 weeks whose mothers wished to provide expressed breast milk were eligible for study. Babies were excluded if total intravenous alimentation apart from dextrose alone was required or if ventilation was required beyond the end of the first week. The study was stopped in an individual baby when the baby was discharged or transferred out of Nottingham or the predominant feed was changed from expressed breast milk to an artificial milk. 